\title{
Individual variation in seasonal movements and foraging strategies of a land-locked, ice-breeding pinniped
}

\author{
Lilia Dmitrieva ${ }^{1, *}$, Mart Jüssi' ${ }^{2}$, Ivar Jüssi' ${ }^{2}$, Yesbol Kasymbekov ${ }^{3}$, Mikhail Verevkin ${ }^{4}$, \\ Mirgaliy Baimukanov ${ }^{3}$, Susan Wilson ${ }^{5}$, Simon J. Goodman ${ }^{1, *}$ \\ ${ }^{1}$ School of Biology, University of Leeds, Leeds LS2 9JT, UK \\ ${ }^{2}$ Pro Mare MTÜ, Saula, Kose, Harjumaa 75101, Estonia \\ ${ }^{3}$ Institute of Hydrobiology \& Ecology, Karasaysky Raion, Almaty 040916, Kazakhstan \\ ${ }^{4}$ St. Petersburg State University, Universitetskaya nab.7/9, St. Petersburg 199034, Russia \\ ${ }^{5}$ Tara Seal Research, Killyleagh, Co. Down BT30 9QN, UK
}

\begin{abstract}
Marine mammal satellite telemetry studies can provide important tests of movement and foraging theory. Here we present the first satellite tracking study of Caspian seals Pusa caspica, an endangered, ice-breeding phocid seal, endemic to the Caspian Sea. The Caspian Sea is one of the most variable habitats inhabited by any pinniped species, and lacks competing large piscivores. Under such conditions foraging theory predicts that individual variation in foraging strategy may develop to reduce intra-species competition. We deployed 75 Argos satellite tags from 2009 to 2012 on adult seals of both sexes, and used state-space modelling to describe movement, and behavioural states. During winter in all years most individuals were mobile within the icepack, making repeated trips into open water outside the ice field, with only brief stationary periods that may have been related to breeding activity. During summer 2011, $60 \%$ of tagged animals migrated into the mid and southern Caspian, while the remainder spent the ice-free season in the north. Summer foraging locations were not restricted by proximity to haul-out sites, with animals spending more than 6 months at sea. Maximum dive depths exceeded $200 \mathrm{~m}$, and maximum duration was greater than $20 \mathrm{~min}$, but $80 \%$ of dives were shallower than $15 \mathrm{~m}$ and shorter than 5 min. Hierarchical cluster analysis identified 3 distinct groups of summer dive behaviour, comprising shallow, intermediate and deep divers, which were also spatially exclusive, suggesting potential niche partitioning and individual specialisation on prey or habitat types. The results can contribute to assessment of impacts from anthropogenic activities and to designation of protected areas encompassing critical habitats.
\end{abstract}

KEY WORDS: Caspian seal · Foraging ecology · Migration · Habitat specialisation · Diving behaviour $\cdot$ Kazakhstan $\cdot$ Russian Federation

\section{INTRODUCTION}

Understanding the causes, mechanisms and spatiotemporal pattern of animal movements is important for testing foraging theory, for understanding species responses to environmental change and for conservation (Nathan et al. 2008, Bestley et al. 2013). Move-

${ }^{*}$ Corresponding authors: sealilia@gmail.com,

s.j.goodman@leeds.ac.uk ment patterns can be driven by the spatial and temporal distribution of resources and habitat, and by the need to reduce inter- and intra-species competition. Migratory species or those living in seasonal habitats may move in response to changes in the spatiotemporal distribution of food resources, climate envelope, or physical features such as breeding sub-

(C) The authors 2016. Open Access under Creative Commons by Attribution Licence. Use, distribution and reproduction are unrestricted. Authors and original publication must be credited. 
strates. Similarly, they may use movement to partition themselves spatially or temporally from competitors. One of the most effective ways to study movement patterns of marine mammals is through satellite telemetry, which has been used to address questions relating to resource selection, foraging strategy, dispersal, migration, home range, survival, population abundance and distribution (Folkow et al. 2004, Lake et al. 2006, Freitas et al. 2008a, Dietz et al. 2013).

Pinnipeds provide some important tests of movement and foraging theory in relation to resource distribution, seasonal habitat variation and competition reduction. Temporal, vertical and horizontal prey distribution, and meteorological and oceanographic conditions have been shown to determine movement and foraging behaviour of different pinniped species, e.g. wind speed and light for northern fur seals Callorhinus ursinus (Sterling et al. 2014); water temperature for southern elephant seals Mirounga leonina (Bestley et al. 2013), temperature, bathymetry and chlorophyll for hooded seals Cystophora cristata (Andersen et al. 2013), and ice coverage for ringed seals Pusa hispida (Freitas et al. 2008b). Movements of central place foragers (species that make regular short-duration foraging trips to defined feeding areas) can be limited by proximity to haul-out sites, which they use for resting or feeding pups, as seen in harbour seals Phoca vitulina (Thompson \& Miller 1990), grey seals Halichoerus grypus (Harvey et al. 2012) and otariids during breeding seasons (Thompson et al. 2003). Risk of predation (De Vos \& O'Riain 2013), interspecies competition (Villegas-Amtmann et al. 2013) and physiological state (Kelly et al. 2010, Crawford et al. 2012) also influence movement patterns and habitat use.

The Caspian seal Pusa caspica is a small-bodied, ice-breeding phocid, endemic to the Caspian Sea. The species is listed as 'Endangered' by the International Union for the Conservation of Nature (IUCN), having declined by around $90 \%$ from a population exceeding 1 million individuals at the start of the $20^{\text {th }}$ century, due to unsustainable hunting. It is subject to a range of threats including high levels of mortality from fishing by-catch and other anthropogenic sources, and habitat loss and disturbance caused by industrial and urban development. Impacts on food webs from invasive species and overfishing, disease, pollution and climate change may pose additional threats but are poorly studied (Härkönen 2008, Härkönen et al. 2008a, 2012, Dmitrieva et al. 2013, 2015).

There is little information about Caspian seal movements. It is assumed that there is a single, panCaspian population, making seasonal migrations be- tween northern and southern basins (Badamshin 1969). Breeding animals gather on ice in the Northern Caspian in January to March for pupping and mating. After the breeding period all adult and subadult seals begin their annual moult (late March to May) on the ice and then on islands and peninsulas following the ice melt in mid-March to early April. After moulting, seals are assumed to disperse for foraging throughout the Caspian. In early autumn the seals return north and haul out on islands before ice forms. Seals keep to open ice areas until they choose appropriate ice-platforms for breeding. Seal distribution will subsequently depend mostly on ice movements (Badamshin 1969). However, the actual movements of seals, location of the feeding grounds and time they spend in particular areas are all unknown. Similarly, there is no systematic information about Caspian seal diving and foraging behaviour. During the summer feeding period it is not known whether Caspian seals are central place foragers or whether they make itinerant searches for resources.

The Caspian Sea, the world's largest landlocked water-body, represents one of the most extreme and variable habitats inhabited by any pinniped species. Air temperature in the region can range from $+40^{\circ} \mathrm{C}$ in summer to $-35^{\circ} \mathrm{C}$ in winter, with an ice field covering the shallow northern basin from late December to early April each year, and subtropical conditions in the southern portion. Habitats range from extensive river deltas around the inflow of the Volga and Ural rivers, with large areas of reed beds and shallow water depths in the north, to deep basins of more than $1000 \mathrm{~m}$ in the southern Caspian. There are opportunities for both benthic foraging in shallow water and on basin slopes, and for pelagic foraging in the deep offshore water. This physical variation, alongside spatial and temporal variation in biological resources, may create opportunities for individual specialisation in Caspian seals. The absence of other competing large piscivorous predator species may also allow exploitation of these niches to reduce intraspecies competition. In addition, over the course of historical and geological time there has been extensive fluctuation in sea level, affecting the relative amounts of shallow and deep habitat (Svitoch 2012), which may promote evolution of plasticity in foraging strategies. Together, these factors could drive the development of substantial variation in individual movement patterns and foraging behaviour among Caspian seals.

In this paper we present the first extensive study of Caspian seal movement, based on deployments 
of tags on 75 individuals, spanning 4 consecutive years (2009 to 2012). We assess seasonal dispersal at the population level and individual variation, describe basic movement parameters and dive capabilities of Caspian seals, and test whether there is variation in foraging strategy among individuals. The results are relevant for identifying important habitat areas and the design of conservation strategies for the species.

\section{MATERIALS AND METHODS}

\section{Study sites, instrumentation and data collection}

Caspian seals were captured at 2 sites in Kazakhstan (Fig. S1 in the Supplement at www.int-res.com/ articles/suppl/m554p241.pdf): on Kendirli sand bank $\left(42.75^{\circ} \mathrm{N}, 52.55^{\circ} \mathrm{E}\right)$ in October to November 2009, 2010 and 2012, and in Komsomolets Bay in April $2011\left(45.51^{\circ} \mathrm{N}, 52.63^{\circ} \mathrm{E}\right)$. Kendirli is a haul-out site primarily used by seals in spring and autumn, while Komsomolets Bay is the major spring moulting site for the species, with aggregations comprising tens of thousands of animals present from April to early May (Fig. S2 in the Supplement).

Seals were caught using a 'rush-and-grab' approach with hoop nets, or using tangle nets deployed in shallow waters around haul-out groups from rigidinflatable boats. Animals were restrained and handled without the use of chemical immobilization and released immediately after the tagging procedure (Gales et al. 2009). Satellite tags were attached to the seal's head fur with epoxy glue (Fedak et al. 1983, Mazzaro \& Dunn 2009). In total 75 seals were tagged: 5 adults ( 3 females and 2 males) in November 2009; 22 adults (20 females and 2 males) in October 2010; 33 adults (9 females and 24 males) in April 2011 and 15 adults (10 females and 5 males) in October 2012. Body size measurements are given in Table $\mathrm{S} 1$ in the Supplement at www.int-res.com/articles/suppl/m554 p241_supp.pdf. BMI (body mass index), estimated as:

$$
\frac{\text { body mass }}{\text { body length }^{2}}
$$

(with body mass in $\mathrm{kg}$ and body length in $\mathrm{m}$ ) was used as a simple measure of relative fatness or body condition. Comparison of body lengths to male and female growth curves for Caspian seals (Wilson et al. 2014), suggest that all the animals were sexually mature individuals. Body length was measured as linear nose to tip of tail distance along the side of the animal.
Two types of satellite tags were used in this study: (1) 42 Smart Position-Only Tags (SPOT5, Wildlife Computers), which return location and wet/dry data, were deployed from 2009 to 2012; (2) 33 SPLASH Mk10 tags (Wildlife Computers), which provide position and information on diving and haul-out behaviour, were deployed from 2010 to 2012. Tags were deployed with a transmission budget of 250 to 300 transmissions per day with no duty cycling.

Data from tags were returned via the Argos satellite system (https://argos-system.cls.fr). Argos signal data were decoded using the manufacturer's software (WC-DAP 3.0, Wildlife Computers). Argos positions and other tag data were then imported into ArcMap 10.0, and the ' $\mathrm{R}$ ' statistical package (R Core Team 2014) was used for further analysis. The Geospatial Modelling Environment (GME) (Beyer 2012) extension for ArcGIS 10.0 was also used in spatial analysis.

\section{Data filtering and path prediction}

Argos location data were pre-processed to remove the worst outliers before applying further statistical analyses such as Bayesian state-space modelling (SSM) (Patterson et al. 2010, Robinson et al. 2012). Firstly, we removed isolated locations on land, and locations which were considered to have been transmitted after a potential death of an animal, or tag shedding (i.e. the same positions transmitted for several days at the end of a track prior to loss of signal). Secondly, remaining locations were filtered with the 'Argosfilter' R package, removing locations requiring travelling velocities of greater than $2 \mathrm{~m}$ $\mathrm{s}^{-1}$, or turning angles greater than $155^{\circ}$ (Freitas et al. 2008c).

In order to account for location observation error, estimate movement parameters and predict behavioural mode (foraging or travelling), 2-state switching correlated random walk (CRW) models (Jonsen et al. 2005, Breed et al. 2009), were fitted using SSM with WinBUGS (Lunn et al. 2000) and R (R Core Team 2014), following (Breed et al. 2009). For temporal regularisation of the data we selected 480 min ( 3 positions $\mathrm{d}^{-1}$ ) time steps for 2009 data and 288 min ( 5 positions $\mathrm{d}^{-1}$ ) for higher resolution 2010, 2011 and 2012 data. To evaluate potential bias due to pre-processing we examined SSM performance on both raw data and pre-processed data. Outputs from the SSM using pre-processed data had fewer locations unassigned to behavioural 
states, and the tracks were a better visual fit than those based on raw data. Therefore, further statistical analysis is reported for the pre-processed data.

The specified priors for all unknown parameters are presented in Table S2 in the Supplement. Due to the large size of the dataset, the 75 seal tracks were divided into 15 independent sets each containing 3 to 8 tracks. Tracks within groups were from the same year and where possible contained tracks of seals of one sex or/and showing similar movement patterns. Model parameters were estimated for each group of tracks.

Each data group was run in 2 Markov Chain Monte Carlo (MCMC) simulations for 10000 iterations, with a burn-in period of 5000 iterations. After each run the chain history plot was checked for 'mixing' and stationarity (Breed et al. 2009). Since there are no available methods for validation of these SSM models (Jonsen et al. 2006, Breed et al. 2009), we compared estimated parameter means for behavioural states using Wilcoxon rank-sum correlation tests. The results were then imported into ArcGIS to assess the fit of tracks visually. Confidence in correct categorisation of behavioural state was high when the proportion of MCMC samples fit to the particular state was very low $(<0.3)$ or very high $(>0.7)$. Uncertain locations (with proportions between 0.3 and 0.7 ) and locations on haul-out sites and those within $2 \mathrm{~km}$ of the shore were excluded from further track analysis in order to minimise errors related with inability of SSM to separate haul-out behaviour from foraging due to low signal-to-noise ratio in Argos data (Breed et al. 2009).

\section{Summary analyses}

All tracks were mapped for visual comparison and general movement patterns were described. Since it was not possible to recover tags and access full records archived on board, diving and temperature data for the 33 SPLASH tags were converted to $6 \mathrm{~h}$ summaries for return via the Argos system. The summarised data gives the proportion of dives, dive times, time at depth and time at temperature, over 14 intervals specified for each data type, for $6 \mathrm{~h}$ time windows (Wildlife Computers 2011). Summaries of maximum dive depth and duration were made, along with percentage of each hour the tag was 'dry' (out of the water for at least $30 \mathrm{~s}$ in each minute). Summary dive data was visualised and analysed in $\mathrm{R}$ using custom scripts.

\section{Track analysis}

All tracks were divided into segments based on SSM behavioural states, and a range of track properties were measured using R, ArcMap 10.0 and the GME extension for ArcGIS 10.0, including: track length; number of foraging and travelling locations; lengths of segments of each behavioural state; foraging areas (areas with 3 or more consecutive foraging locations were quantified by minimum convex polygons); and length of time at each foraging area.

\section{Analysis of individual foraging variation}

Hierarchical cluster analysis (HCA) was conducted to classify summer foraging strategies for tags deployed in April 2011 (Villegas-Amtmann et al. 2013). The following diving variables from the period May to September were used to classify individuals: dive depth, dive duration and time at depth. The following behaviour parameters were then compared among HCA groups: maximum depth of dives; number of dives; movement speed; percentage time spent at the surface; proportion of time spent foraging; and size of foraging area.

\section{RESULTS}

\section{Data return rates and transmission periods}

After initial filtering we obtained 93138 Argos positions from all 75 tags. The mean number of positions per day per tag ranged between 0.8 and 13.7 (Table S3 in the Supplement). The longest periods of transmission (about 11.5 months) were achieved by tags 72500 and 72562 deployed in April 2011. Tag 72562 also had the longest estimated track, at approximately $14400 \mathrm{~km}$. There was no significant correlation between deployment length and measures of body size or condition (weight, length or $\mathrm{BMI}$; Spearman rank correlation test, $\mathrm{p}>0.05$ in each case).

In 2 cases, patterns of tag loss were consistent with seals being by-caught or killed and the tags/carcasses disposed of on shore. Tag 57025 stopped transmitting between 9 and 13 February 2010, and resumed returning locations from Sulak (a fishing port) in Dagestan (43.27 N, 47.51 E). After 3 months of normal movement patterns, tag 57055 started transmitting from a single onshore location of the Azerbaijan coast (40.86 N, 49.4 E) after 18 August 2011. 


\section{Overview of tracks and seasonal movement patterns}

Over all deployments the mean daily distance travelled was $32.6 \mathrm{~km}$ $\mathrm{d}^{-1}$ (SD $10.36 \mathrm{~km}$, range 7 to $58 \mathrm{~km}$; Table S3). From December to April, the median latitude of locations was around $45^{\circ} \mathrm{N}$, with seals on the northern ice for breeding before dispersing to moulting locations in the northern basin in April (Fig. 1). May to September saw a switch to a more southerly distribution (median 42 to $43^{\circ} \mathrm{N}$ ), coincident with an increase in sea surface temperature (SST) (Fig. 1) and net primary productivity (NPP) (not shown), based on SST and NPP data taken from NASA's Ocean Color Web (http:// oceancolor.gsfc.nasa.gov/). This was followed by a return to more northerly latitudes in October to November alongside declining SST. During the study period mean SST for the whole Caspian varied from $+6^{\circ} \mathrm{C}$ in February to $+27^{\circ} \mathrm{C}$ in July. Throughout all months there was considerable variation in latitudinal distributions.

\section{Summer movements}

Seals tagged at the end of the moult in Komsomolets Bay in spring 2011 dispersed south, west or south-west in the last $2 \mathrm{wk}$ of April, travelling towards summer feeding areas. Five distinct movement patterns were observed (Fig. 2): (1) Thirteen of 33 seals (10 males, 3 females) remained in the north Caspian in water depths not exceeding $20 \mathrm{~m}$ (Fig. 2a). (2) Three males moved directly into deep waters in the mid Caspian where depths varied from $20 \mathrm{~m}$ to $600-700 \mathrm{~m}$ (Fig. 2b). (3) Four seals (3 males, 1 female), moved to the west coast of the mid Caspian between Makhachkala (Russia) and Sumgait (Azerbaijan), congregating in an area where the seabed slopes from 5 to $700 \mathrm{~m}$ over approximately $30 \mathrm{~km}$ (Fig. 2c). (4) Three other individuals (2 males, 1 female) moved along the eastern coast to the mid Caspian between Kendirli Bay and the southern edge of Kara-Bogaz-Col, using an area from the shore to the $200 \mathrm{~m}$ bathymetric contour (Fig. 2d). (5) Ten seals ( 7 males, 3 females) migrated as far as the southern Caspian basin, predominantly following routes along the western or eastern coasts, through waters with depths varying from 50 to $200 \mathrm{~m}$ (Fig. 2e). Tracks of some individuals (e.g. 57062, 57070 and 72554) crossed waters with depths exceeding $800 \mathrm{~m}$. The most southerly position $(36.90 \mathrm{~N}$, $52.69 \mathrm{E}$ ) was recorded by male 57070 in June, around $19 \mathrm{~km}$ from the Iranian coast. Animals in both the north and mid/southern Caspian Sea were consistently mobile during the summer months (May to September) with most daily tracks exceeding $20 \mathrm{~km}$ $\mathrm{d}^{-1}$ (mean $\pm \mathrm{SD} 21.62 \pm 7,63 \mathrm{~km}$, range 8.95 to $37.67 \mathrm{~km})$.

\section{Autumn movements}

Animals tagged at Kendirli in the 3 autumn deployments from 2009 to 2012 showed a range of movement patterns (Fig. 2f, Fig. S3 in the Supplement). Most animals swam between 300 and $500 \mathrm{~km}$ directly to the North Caspian within 2 wk of tagging, while a minority remained in the Gulf of Kendirli (within $100 \mathrm{~km}$ ), making regular return visits to the vicinity of the tagging site until early January (seal 57046, Fig. S3a). In 2009, 1 individual (98186) travelled 


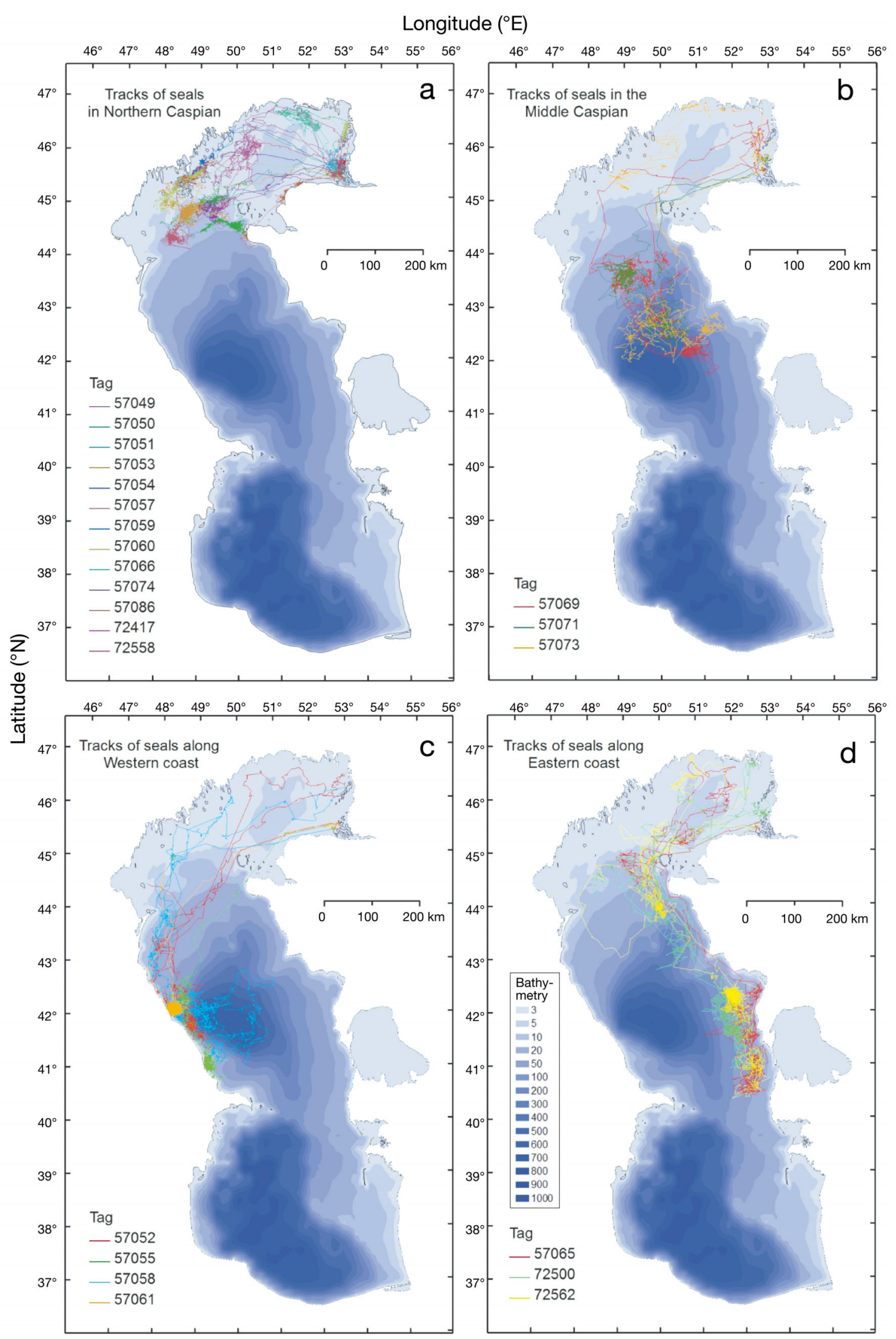

Fig. 2. Movement patterns for Caspian seals tagged in April 2011 and tracked in the (a) northern and (b) mid Caspian Sea, and along the (c) western and (d) eastern coasts. (e) Tracks of seals that moved to the southern Caspian Sea. (f) Representative tracks from autumn deployments. (g) All locations where tags were 'dry' (i.e. out of the water) for 25 to $50 \%$ and (h) $>50 \%$ of each $24 \mathrm{~h}$ period 


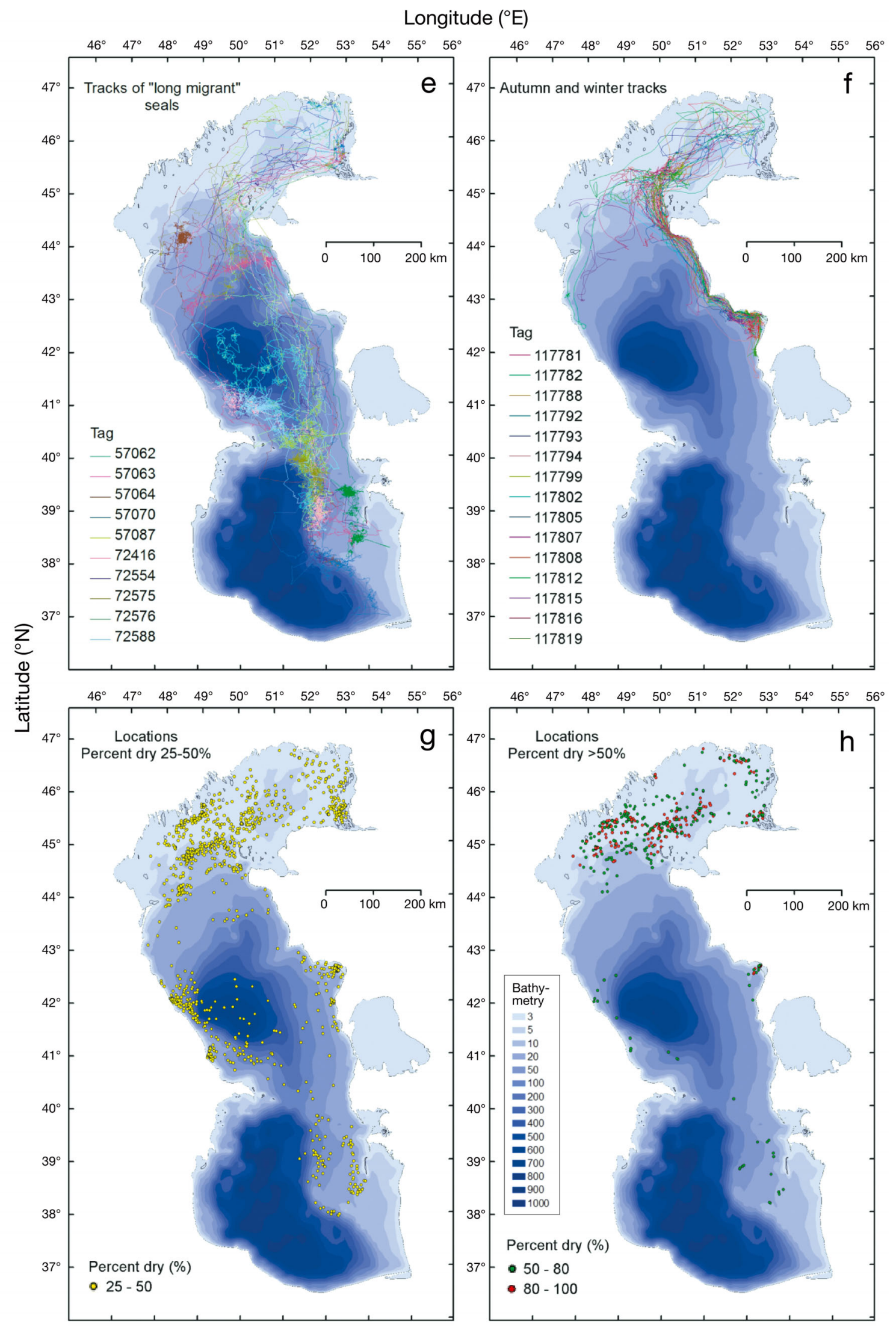

Fig. 2 (continued) 
south to the southern tip of Ogurchinsky Island by early December, before the track was lost. Seals moving into the northern basin during late October and early November (seal 57023, Fig. S3b and seal 57040, Fig. S3c) spent the period prior to formation of the ice sheet in the very shallow water (often $1 \mathrm{~m}$ or less) and reed beds from Komsomolets Bay along the east coast to the Ural delta. Autumn movement into the northern basin along the east coast generally followed a corridor between the coast and the $50 \mathrm{~m}$ bathymetric contour. Animals from the 2009 deployment were late migrants, and did not move north before late December, while seals tagged in April 2011 returned northward between mid-August to early February, following return paths along both west and east coasts, or the central Caspian.

\section{Winter movements}

Over the study period the winter ice sheet formed between late December and early January each year. During formation of the ice sheet most animals moved into the centre of the north basin and were located along the ice edge or within the ice field around the 'Saddle' area. Their locations overlapped with areas of high seal density identified from concurrent aerial population surveys in February in 2010 to 2012 (Dmitrieva 2013, Dmitrieva et al. 2015).

Plots of cumulative distance travelled and distance from the tagging site against deployment date indicated that during the ice period most seals (33 from 48 active during ice periods) were mobile, with consistent movement rates, and demonstrated few stationary periods in the ice (Fig. S3a,b). Fifteen seals (11 females, 4 males) exhibited sedentary periods, and were stationary or had relatively low movement rates (within areas of up to $20 \mathrm{~km}$ radius) for 2 to $8 \mathrm{wk}$ in January to March (e.g. Fig. S3c). Mobile animals moved within the ice area, with most making trips to the ice edge, or northern slope of the central basin, and some travelling as far south as Aktau and the Gulf of Kendirli, entering and leaving the ice field several times over the season (e.g. tags 57023, 57087, 72575). Seventeen seals remained active until ice break up in mid-March to early April, associating with surviving ice flows, or moving to the moulting site of Maly Zhemchuzhny Island $\left(45.05^{\circ} \mathrm{N}, 48.32^{\circ} \mathrm{E}\right)$ in Russia, or towards Komsomolets Bay.

\section{Haul-out locations and resting behaviour}

Little hauling out was recorded in the post-moult ice-free period (May to December), with many animals at sea for more than 6 mo (Fig. 3). Extended surface/resting intervals with 25 to $80 \%$ total time dry per day were observed along seal tracks from near-shore coastal waters to far offshore areas up to $800 \mathrm{~m}$ in depth in the mid and southern Caspian (Fig. 2g,h). Positions with the longest surface/resting intervals $\left(>80 \%\right.$ dry $\mathrm{d}^{-1}$ ), were only seen around small islands and in shallow coastal areas of the north Caspian. Overall mean 'dry' surface time per day ranged from around 25 to $30 \%$ in the ice-free period to more than $40 \%$ in the February to March breeding period (Fig. 3).

\section{Behaviour states and comparison of movement parameters}

SSM revealed 2 significantly different movement patterns $(\mathrm{p}<0.001)$ representing 2 behavioural states: 'foraging' with slow movement (mean $\pm \mathrm{SD}$ : 0.7 $\pm 0.45 \mathrm{~km} \mathrm{~h}^{-1}, 39486$ locations) and 'travelling' with faster movements $\left(2.4 \pm 0.56 \mathrm{~km} \mathrm{~h}^{-1}, 13356\right.$ locations, Table S4 in the Supplement). The state of $9.8 \%$ (5765) of modelled locations were uncertain. The SSM parameter estimates for each behavioural state are within the range of those estimated for grey seals (Tables S5 \& S6 in the Supplement; Breed et al. 2009). 'Northerners' (seals that stayed in the northern Caspian) travelled an average $23.9 \mathrm{~km} \mathrm{~d}^{-1}$

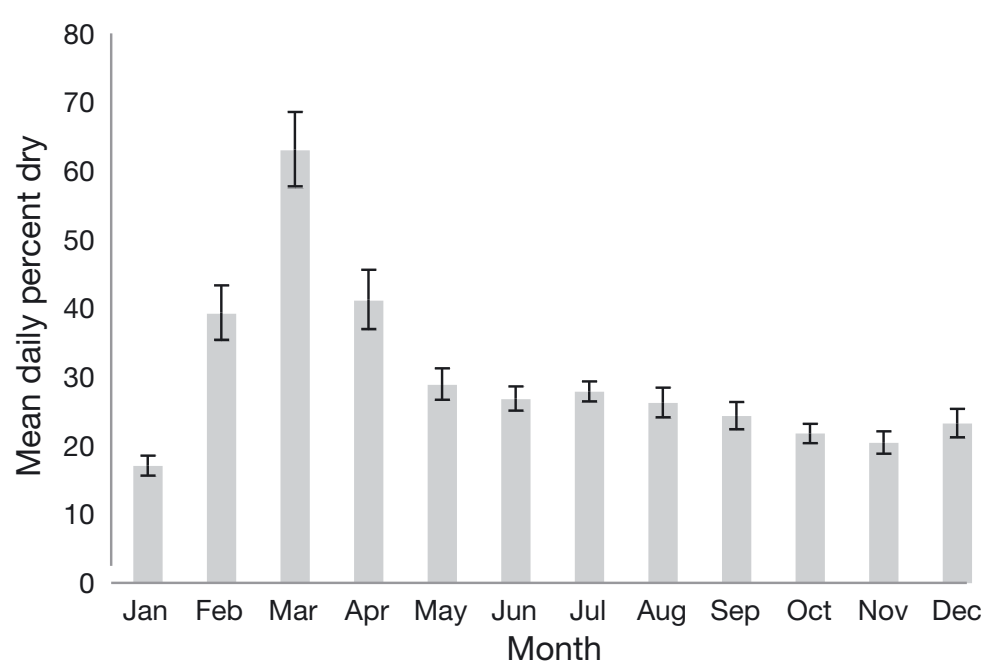

Fig. 3. Seasonal variation in average daily proportions of time spent dry (at surface) for all Caspian seals tracked from 2009 to 2014. Standard errors are indicated by bars 
compared to $43.1 \mathrm{~km} \mathrm{~d}^{-1}$ for 'migrants' into the mid and southern Caspian (2-sample $t$-test: $t=5.943, \mathrm{p}<$ 0.001).

Average size of foraging areas ranged from 34.5 to $3002 \mathrm{~km}^{2}$ among individuals (mean \pm SD: $848.6 \pm$ $773.0 \mathrm{~km}^{2}$ ). Males used significantly larger foraging areas $\left(1383.0 \pm 1992.8 \mathrm{~km}^{2}\right)$ than females $(496.1 \pm$ $1036.1 \mathrm{~km}^{2}$ ) although the dispersion within the individual tracks and among the individual seals was very high (Wilcoxon rank test with continuity correction, $W=23366$, $\mathrm{p}<0.0001$ ). A more detailed analysis of habitat use in relation to environmental correlates will be presented in a separate paper.

\section{Diving behaviour and variation in foraging strategies}

Maximum dive depths observed within $6 \mathrm{~h}$ summary periods ranged from $1.5 \mathrm{~m}$ to more than $200 \mathrm{~m}$; overall mean maximum dive depth was $33.5 \mathrm{~m}$ (SD

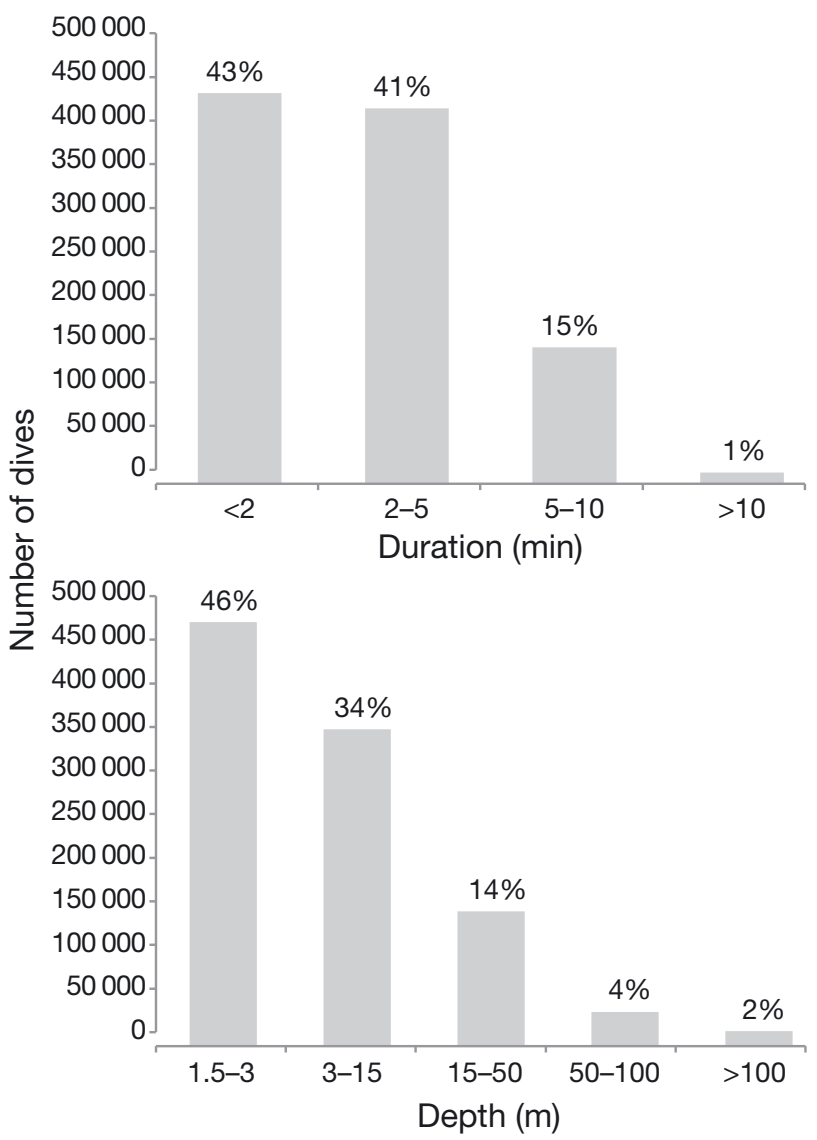

Fig. 4. Proportion and number of dives of different (a) depth and (b) duration intervals for 33 Caspian seals over the deployment period 2009-2014 based on $6 \mathrm{~h}$ records (12 188 dive depth records and 11443 dive duration records)
$49.1 \mathrm{~m}$ ) for the whole dataset (Fig. S4 in the Supplement). There was considerable variation in the diving behaviour of individual seals. Mean maximum depth for individual tags varied from 6.5 to $122 \mathrm{~m}$. Nine seals performed dives deeper than $100 \mathrm{~m}$, including 6 animals with dives exceeding $200 \mathrm{~m}$ (Table S7 in the Supplement). For males, maximum dive depths exceeding $200 \mathrm{~m}$ were recorded from April to October, while for females such maximums were only observed in May to July. Monthly average maximum dive depths were relatively shallow in November to March for both males and females, while the highest monthly average maximum depth was in June for females and in September for males (Table S8 in the Supplement). Dives shallower than $3 \mathrm{~m}$ accounted for around $50 \%$ of all dives; $80 \%$ of the dives were shallower than $15 \mathrm{~m}$, with only $6 \%$ of dives deeper than $50 \mathrm{~m}$ (Fig. 4). Most dives (84\%) were less than $5 \mathrm{~min}$ long, and the maximum recorded dive durations exceeded 20 min (Fig. 4).

Representative diving timelines for 3 seals in the period April to November 2011 are presented in Fig. 5. Five of 15 seals fitted with time-depth recorders over summer 2011 showed a pattern of exclusively shallow diving behaviour (e.g. Fig. 5a), contrasting with others which exhibited consistent intermediate or deep diving (Fig. 5b,c). A HCA of the summer 2011 (May to September) diving variables identified 3 clusters with significantly different diving behaviours (Fig. 6a): shallow divers (5 seals), intermediate divers ( 3 seals) and deep divers ( 7 seals). The clusters are also partitioned into distinct, nonoverlapping geographic areas defined by SSM foraging locations, with the shallow and intermediate groups comprising only seals which stayed in the north Caspian for the whole 2011 study period (Fig. 6b). Foraging locations for shallow divers corresponded with areas of reeds in the north east Caspian and the Volga delta in the northwest, while foraging locations for intermediate divers were concentrated on the northern slope of the mid-Caspian basin, west of the Mangyshlak peninsula, up to the $20 \mathrm{~m}$ bathymetric contour. The deep divers comprised only animals which migrated into the middle and southern basins. Significant differences were found among the behaviour groups' maximum depth of dives (Wilcoxon rank-sum test, $\mathrm{p}<0.001$ ); number of dives ( $t$-test, $\mathrm{p}<0.001$ ); movement speed (Wilcoxon rank-sum test, $\mathrm{p}<0.001$ ); and percentage time spent at the surface (Wilcoxon rank-sum test, $\mathrm{p}<0.05$ ) (Fig. 6c). Proportion of time foraging was lower, and foraging area was greater for the deep dive group, although the differences were not significant. 

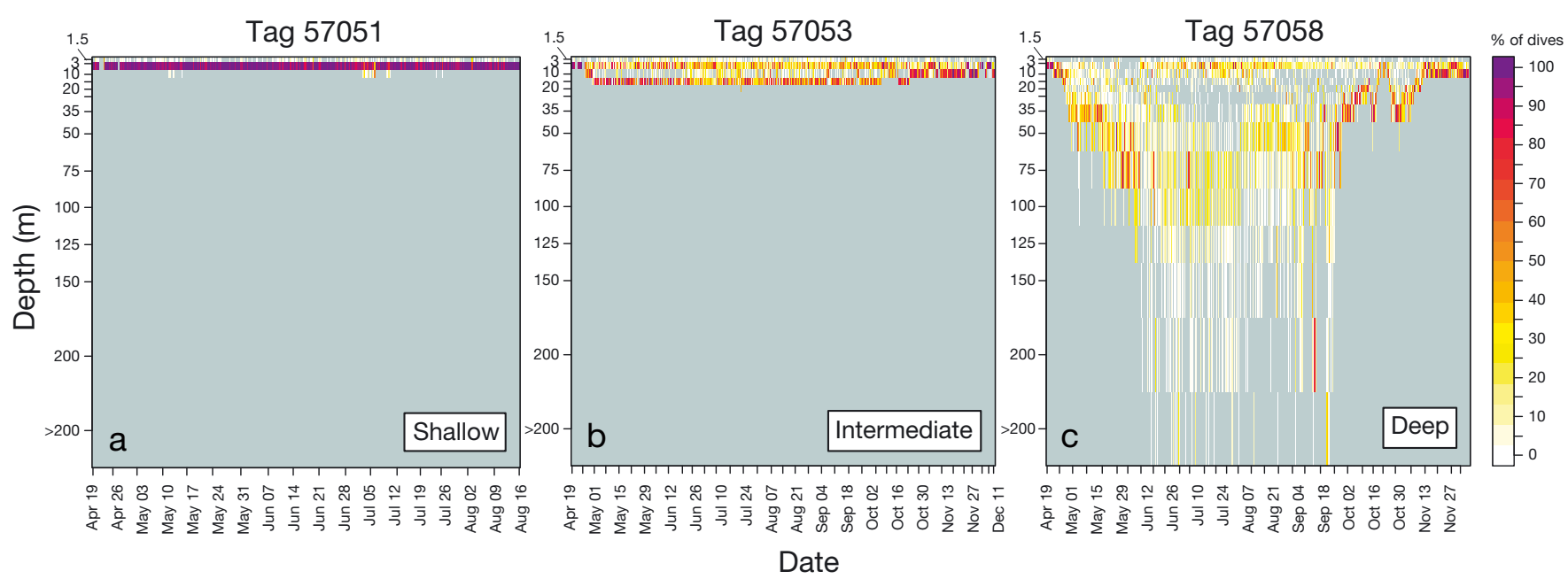

Fig. 5. Summary dive depth timelines for seals tagged in April 2011, illustrating profiles representative of the 3 dive behaviour clusters. Dive depth data are presented by percentage of dives (indicated by the colour scale) falling into particular depth 'bins' (e.g. 1.5-3 m, 3-10 m, 10-15 m etc.) for $6 \mathrm{~h}$ time windows from the start of the deployment. (a) Shallow diver, tag 57051: all dives not deeper than $15 \mathrm{~m}$ and most dives were in the range of 3 to $7 \mathrm{~m}$ during whole deployment period (April to August). (b) Intermediate diver, tag 57053: dives not deeper than $20 \mathrm{~m}$ during whole deployment period. (c) Deep diver, tag 57058: depth of dives increased to the 50-100 m range at the end of May and then continued primarily in the same range during the summer, with periodic deep dives up to $200 \mathrm{~m}$ and more. In October most dives were in the range 20 to $40 \mathrm{~m}$ and by November no dives were deeper than $15 \mathrm{~m}$

Mean body weight at tagging did not differ significantly among the dive clusters (Fig. S5a in the Supplement; Kruskal-Wallis rank sum test, $\mathrm{p}>0.05$ ). Deep and intermediate divers had similar mean body lengths (119.8 and $121.3 \mathrm{~cm}$ respectively), while shallow divers were significantly longer $(133.6 \mathrm{~cm})$, (Fig. S5b; Kruskal-Wallis rank-sum test, $\chi^{2}=7.4342$, $\mathrm{df}=2, \mathrm{p}=0.0243$ ). Consequently shallow divers had significantly lower mean BMI (23.42), than deep (28.2) and intermediate divers (30.9) (Fig. S5c; Kruskal-Wallis rank sum test, $\chi^{2}=7.7348, \mathrm{df}=2, \mathrm{p}=$ 0.02091). HCA for both the 2011 data, and the 2010 and 2012 autumn deployments did not reveal any significant differences in diving behaviour during the autumn and winter period (October to March).

\section{DISCUSSION}

\section{Seasonal movements of Caspian seals}

The historic observational view of Caspian seal movements was of a homogeneous migration with seals dispersing from northern moulting sites to the mid and southern Caspian via the east and west coasts from late April, followed by a return to the north Caspian from September (Badamshin 1969). Our data support the broad-scale seasonal movements reported in older literature, with a southerly shift in the median latitude of locations from May to September, coincident with increasing STT and NPP, and a return north from October onwards (Fig. 1) as SST and NPP decline. However, the telemetry data revealed a high degree of individual variation in the timing, destination, and consistency of movement patterns, indicating that migratory movements are much more heterogeneous than previously thought. For the 2011 summer $40 \%$ of seals were 'nonmigrants' spending the whole ice-free season in the north Caspian, while the remainder (20/33) migrated along the coasts into the mid and south Caspian during April to May and returned north over a protracted period, some as early as August, but most between October and December. Based on all deployments, the return migration extended from late summer until the formation of the ice sheet, a much longer period than previously observed. Movement during the winter was similarly heterogeneous. In contrast to earlier assumptions, rather than staying in the ice pack for the whole season, animals made frequent return trips out of the ice, presumably to forage, with some ranging as far south as Kendirli.

The timings of spring and autumn movements derived from telemetry data correspond with biannual peaks of strandings around the Apsheron peninsula in Azerbaijan recorded from the 1970s to present (Wilson et al. 2014), suggesting that those peaks in mortality reflect local increases in seal density arising from seasonal migrations. Observation by Russian authors (Badamshin 1969), together with stranding records and by-catch reports from Iran (authors' unpubl. data) indicate the presence of seals in Iran- 
a

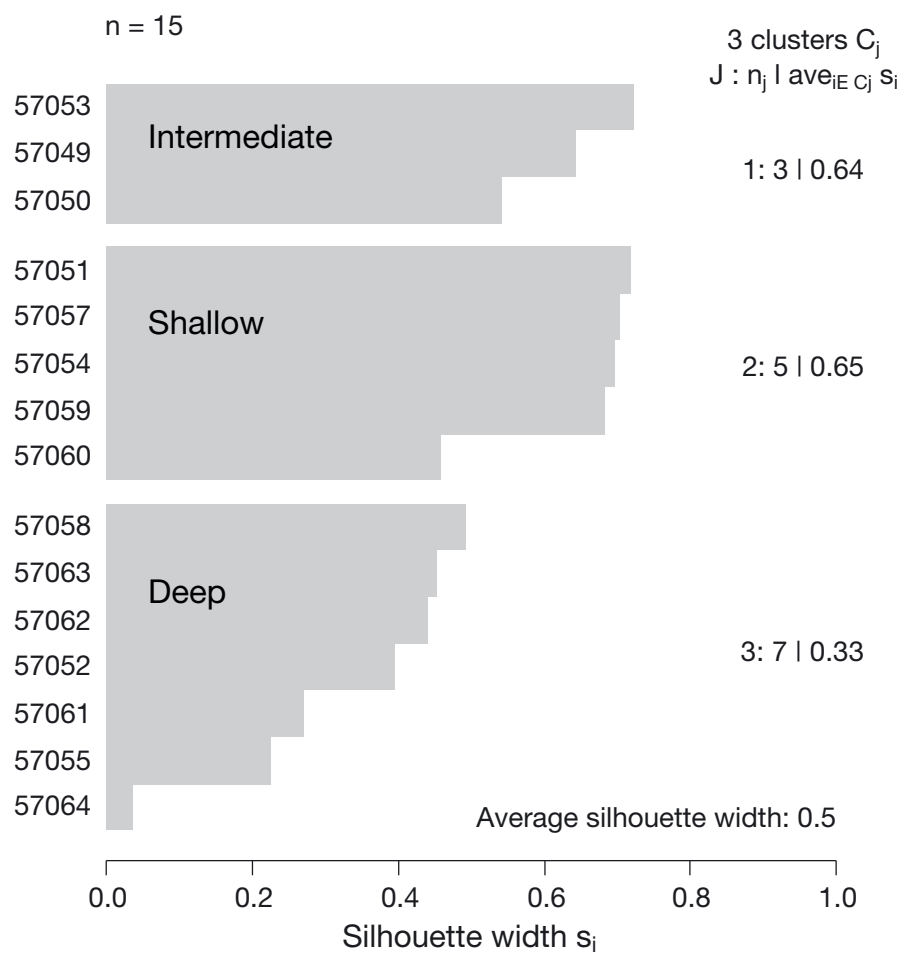

b

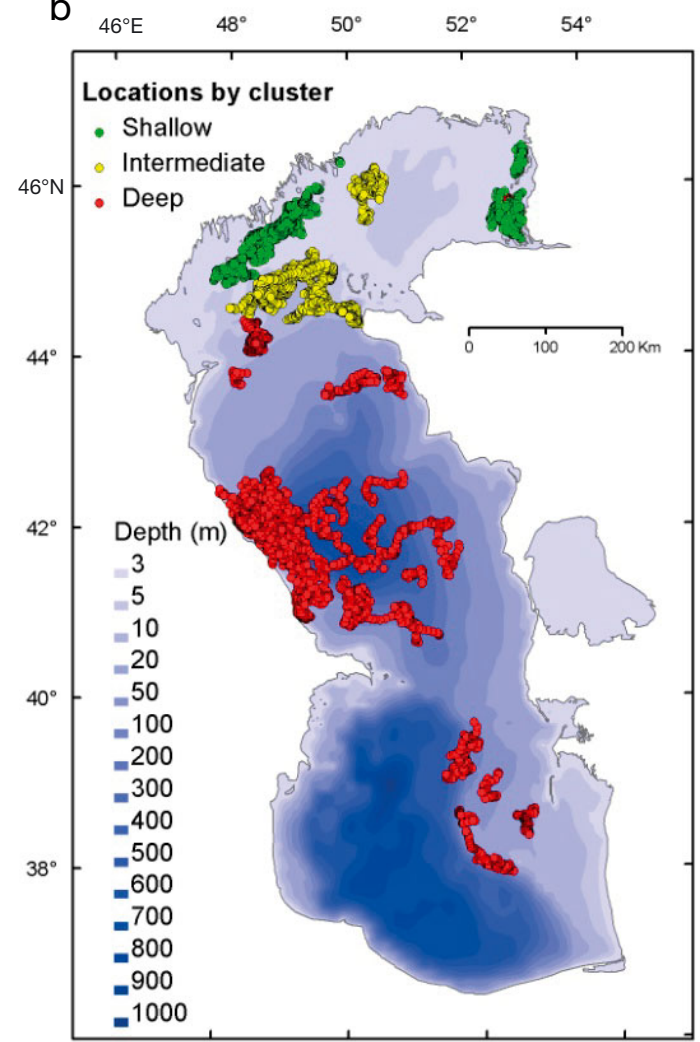

C
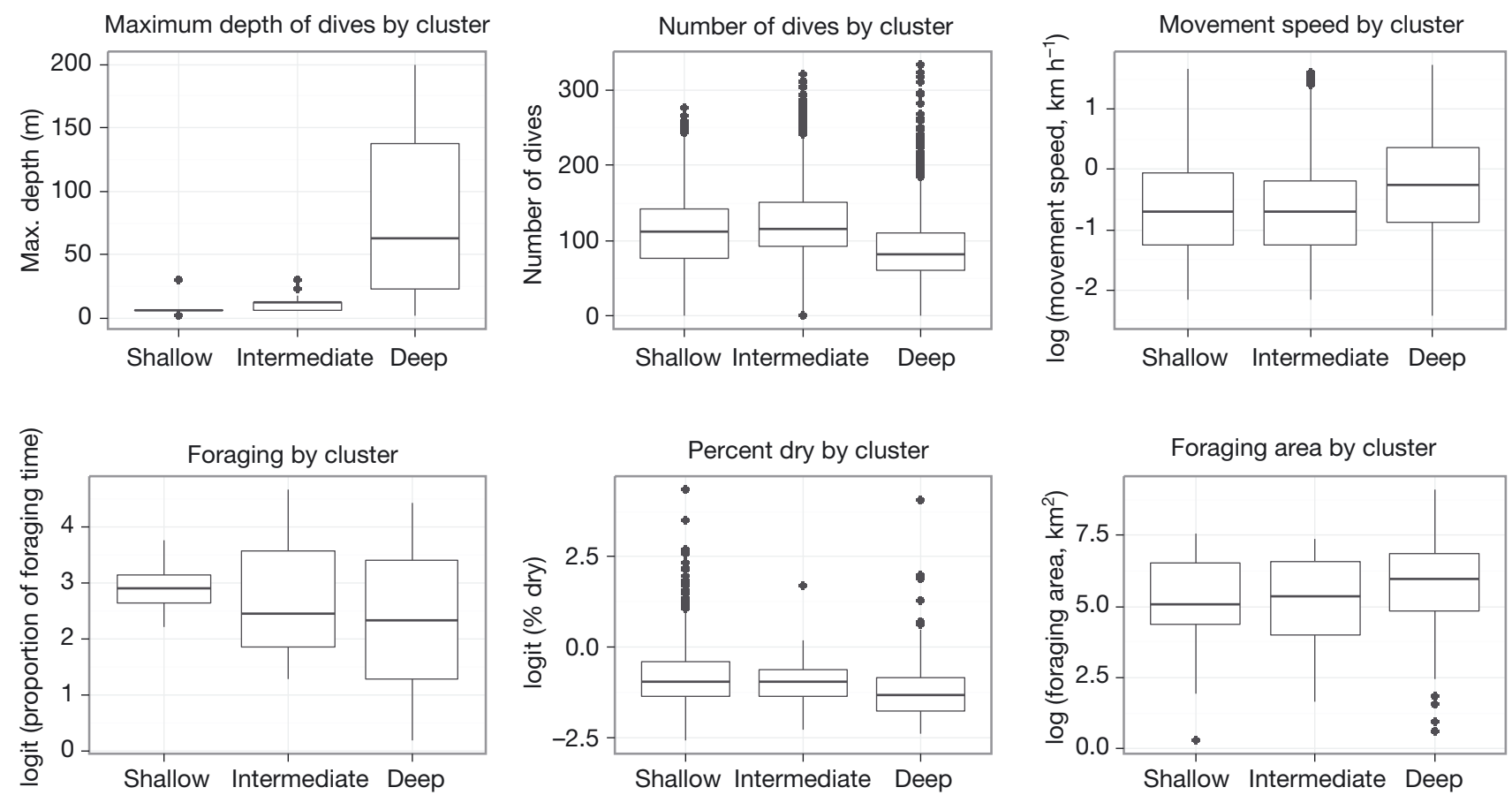

Fig. 6. (a) Silhouette plot, showing 3 clusters of seals tagged with SPLASH tags in 2011 (n = 15). Clusters are produced by hierarchical cluster analysis (HCA) on the basis of summer diving parameters (dive depth, duration and time at depth). $\mathrm{C}_{\mathrm{j}}$ : Cluster $j$ (where $j=1$ to 3$)_{i} n_{j}$ : number of seals in Cluster $j_{i}$ ave $e_{i E} C_{j} S_{i}$ : average width of cluster $j$. (b) Foraging locations identified by state-space modelling (SSM) of seals of 3 dive behaviour clusters. (c) Box-and-whisker plots (see Fig. 1 for explanation) of different behaviour parameters of the 3 clusters of seals 
ian waters throughout the winter. Since all breeding takes place on the northern ice sheet, this suggests that some immature and other non-breeding animals do not migrate. The movements of juveniles remain largely unknown, but observational records suggest young animals use areas around the Ural and Volga deltas during the summer (Badamshin 1969), and the authors have observed pups of the year as far south as Kendirli in May. The tagging of moulted pups on the ice would contribute to understanding movement and habitat use of juveniles.

Overall, the data suggest that Caspian seals are likely to have little population structure since they disperse throughout the whole Caspian from the Komsomolets Bay moulting site, and during the winter animals ranged through the whole breeding distribution in the ice pack identified from aerial surveys (Dmitrieva 2013, Dmitrieva et al. 2015). Such long range dispersal, high mobility, and aggregated breeding is comparable with other ice-breeding species with weak population structure, such as ringed seals in the Arctic, where the annual life history is governed by seasonal and spatial separation of breeding substrate and food resources (MartinezBakker et al. 2013); hooded seals in the North Atlantic where migration patterns reflect favourable foraging conditions (Coltman et al. 2007, Andersen et al. 2013); and in Weddell seals (Chambert et al. 2015).

\section{Resting and haul-out behaviour}

Between May and September 2011, animals showed little evidence of hauling out on land with most individuals at sea for 6 months or more, and there were few records in the vicinity of known current or historical haul-out locations. Locations with extended 'dry' surface intervals $\left(>50 \%\right.$ total dry $\left.\mathrm{d}^{-1}\right)$ were frequently recorded in areas of shallow water in the northeast Caspian and Volga delta outside the ice season, consistent with animals resting on partially submerged mud and sandbanks, or among reed beds. Haul outs are likely to be in the form of individuals or small scattered groups, rather than large aggregations (authors' unpublished data based on coastal helicopter surveys). Surface intervals exceeding $25 \% \mathrm{~d}^{-1}$ were also common in offshore areas throughout the Caspian. Thus, the searching range of the Caspian seals is not restricted by proximity of haul-out sites, and they appear to rest and sleep at the surface while at sea-a behaviour frequently observed by the authors during fieldwork. Therefore in summer they do not need to alternate foraging trips with haul-out behaviour, unlike central place foraging species such as grey seals (Harvey et al. 2012) and harbour seals (Thompson \& Miller 1990, Peterson et al. 2012).

Mean daily 'percent dry time' increased from 25 to $30 \%$ to more than $40 \%$ during February to March. Such behaviour may correspond with breeding activity and could indicate pupping and lactation for females or territorial breeding behaviour for males. Caspian seal pupping peaks during early February, and lactation lasts for around 3 to 4 wk (Badamshin 1966). The active movements of seals over the ice season suggests that unless constrained by breeding or ice conditions they do not spend long periods on the ice sheet and may forage in different locations, supporting observations of females regularly leaving pups on ice to go to sea (Krylov \& Vorozhtsov 1972) and observations of significant numbers of lone pups during aerial surveys (Dmitrieva et al. 2015). This behaviour contrasts with other ice-breeding species such as ringed seals which show higher levels of site fidelity during breeding since they need to maintain breathing holes during the whole ice period (Kelly et al. 2010). Caspian seal surface periods appear similar to other small phocids, e.g. in ringed seals summer at-surface rates are around 10 to $35 \% \mathrm{~d}^{-1}$, and in winter 40 to $45 \% \mathrm{~d}^{-1}$ (Härkönen et al. 2008b).

\section{Individual variation in foraging and diving behaviour}

Foraging areas for males were significantly larger than those of females, although this result should be treated cautiously since our data are not evenly distributed among seasons and sexes, e.g. only 9 females (compared to 24 males) contributed to the summer season data. There is limited sexual dimorphism in Caspian seals (Wilson et al. 2014), and it is unclear whether energetic demands might vary significantly among sexes. Females have costs due to pregnancy and lactation, while males may experience costs due to competition, display and maintaining territories during breeding.

Under optimal foraging theory animals tend to find and consume the food containing the most calories while spending the least amount of time foraging and therefore they are expected to stay longer in areas with higher prey density than others (Charnov 1976, Stephens 2008). Therefore large foraging areas may be related to better foraging habitat than smaller areas. For example, northern fur seals avoided the smallest prey patches and those separated by large 
distances, when their foraging paths were compared to aggregations of prey (pollock) (Benoit-Bird et al. 2013).

Interpreting foraging area size in the current context is constrained by several factors. Firstly, the spatio-temporal resolution of the data is such that foraging areas identified here are likely to constitute hierarchical clusters of foraging patches, rather than individual prey patches (Kotliar \& Wiens 1990, Benoit-Bird et al. 2013), and the delineation of patches can be sensitive to polygon definition assumptions. Secondly, since we employed a 2 state SSM behavioural model to utilise data from both position only and TDR tags, resting and foraging locations may not always be differentiated. Behavioural (area-restricted searching) responses to prey availability can also vary with respect to benthic versus pelagic foraging strategies (Hoskins et al. 2015). Prey species targeted by pelagic foragers may occur in denser aggregations with greater spatial and temporal heterogeneity compared to those selected by benthic foragers. Finally, area-restricted searching behaviour may not be necessarily induced by prey capture success and may rather be related to the environmental features (Weimerskirch et al. 2007). Therefore, the variation in foraging area seen here could be related to a combination of localised seasonal diversity of habitat parameters, and individual specialisation on prey types or foraging strategies.

Overall about $80 \%$ of Caspian seal dives were shallower than $15 \mathrm{~m}$ and shorter than $5 \mathrm{~min}$, which is concordant with results from diving behaviour studies of other small phocids, e.g. Baltic ringed seals (Härkönen et al. 2008b), Arctic ringed seal (Gjertz et al. 2000) and Baikal seal (Stewart et al. 1996). In the shallow north Caspian the majority of dives appeared to make use of the full bathymetry. For the mid and southern Caspian, due to the nature of the diving data (summarised for $6 \mathrm{~h}$ time intervals and into 14 depth bins), there is uncertainty in both the location and depth of individual dives, so it was not possible to determine with confidence the extent to which dives in deep waters were benthic or pelagic (see Fig. S6 in the Supplement), although the bathymetry in the deepest foraging locations visited $(>700 \mathrm{~m})$ is likely to exceed the dive capabilities for small phocids.

The variation in individual diving behaviour raises the possibility that individual seals may specialise in foraging in particular habitats (shallow versus deep divers) or on particular prey species, for at least part of the year. A HCA identified distinct patterns of diving behaviour, partitioning individuals with diving data from summer 2011 into shallow, intermediate and deep divers. The diving clusters were also spatially segregated, with the SSM-derived foraging locations for each cluster split into non-overlapping areas defined by bathymetry. This pattern implies the existence of niche partitioning in response to intra-species competition, with individuals specialising in foraging in different habitats or on different prey types to avoid competitive interactions. This pattern was only detectable during the summer months when animals were feeding to recover from the energetic demands of the previous breeding season and moult, and to build condition for the next season. Partitioning was not significant during the winter when seals are constrained to remain in the north Caspian for breeding. Intra-species competition is likely to be stronger during the winter due to both the seasonal decline in primary productivity and increased population density. This may account for the protracted autumn migration, and movements in and out of the north Caspian during the winter as animals seek to minimise the time spent in a competitive foraging environment while maintaining breeding opportunities.

Niche partitioning in pinnipeds is common among sympatric species, e.g. between Galapagos fur seals Arctocephalus galapagoensis and sea lions Zalophus wollebaeki (Villegas-Amtmann et al. 2013), grey seals and harbour seals (Svensson 2012) and, within species, between juveniles and adults (Crawford et al. 2012, Breed et al. 2013) and mature males and females (Andersen et al. 2013). However, it is less commonly reported among adults of the same sex within species (Kernaléguen et al. 2015), as here. In the Caspian Sea the partitioning may be facilitated by the varied habitats creating a range of exploitable niches, and an absence of other competing large predators. In the ranges of most other seals, species face competition from other pinniped species, cetaceans, sharks and other large piscivorous fish, all of which are absent in the Caspian Sea. Together, these factors could allow foraging specialisation to develop as a mechanism to reduce intra-species competition. In addition, over the 1 to 2 million years seals are estimated to have been present in the Caspian (Fulton \& Strobeck 2010, Nyakatura \& Bininda-Emonds 2012), the sea has undergone several large fluctuations in area and sea level (Svitoch 2012). These changes greatly influenced the habitats, as well as the bathymetry of the sea, and would strongly select for plasticity in foraging behaviour.

Shallow divers had significantly greater body length, and lower post-moult BMI than intermediate 
and deep divers, suggesting that components of body size or relative body condition might influence foraging strategy and niche use. In pinnipeds, relatively 'fatter' animals are more efficient divers (Adachi et al. 2014) and may be better able to exploit deeper habitats, which is consistent with our observation of deep divers having higher post-moult BMI. Alternatively, while it is not possible to estimate the age of mature Caspian seals precisely on the basis of body length, mature seals do continue to grow through adult life (Wilson et al. 2014) so that on average, in our study, shallow divers may have been older than deep divers. Shallow divers' foraging locations were concentrated around the inflow of the Volga delta, which has some of the highest NPP in the Caspian. Therefore, shallow divers may potentially be choosing more productive habitats through experience, and/or competitively excluding younger adults. Shallow divers may also have reduced energetic costs of diving, and to reach feeding areas after breeding and the moult, potentially allowing them to expend more resources on breeding activity.

Conversely, long migrating Caspian seals may trade off the energy costs of longer migration and/or deeper diving against prey with higher energy densities and reduced levels of anthropogenic disturbance. Relatively little information is available about the diet of Caspian seals, but it appears to vary among years, areas and seasons. The summer diet of seals in the North Caspian includes vobla Rutilus rutilus caspicus, gobies Gobiidae spp., juvenile bream Abramis brama and crustaceans, while seals migrating to the mid and south Caspian may feed mainly on oil-rich fish species of the genus Clupeonella (kilka, i.e. deep water anchovy-sprats) and also atherina and gobies (Pochtoeva-Zakharova \& Huraskin 1999). Seals may also target the same species as commercial fisheries in the mid and south Caspian, e.g. kilka taken by trawlers in the southern Caspian and/or herring and shad Alosa braschnikowi taken by seine net fisheries along the Dagestan coast (Pochtoeva-Zakharova \& Huraskin 1999). The main spawning and feeding grounds of some Caspian shad (Bandpei et al. 2012) correspond with apparent core summer seal feeding areas close to river deltas, revealed here.

\section{Interactions with human activities and implications for conservation}

Intensive human activity throughout the Caspian, including fishing, oil and gas extraction, shipping and coastal development overlap with seal movements identified here. The seal 'migration corridor' along the Kazakh coast connecting the north-east and mid Caspian overlaps with intensive shipping and fishing activity. Areas used by seals along the western coast also overlap with commercial fishing grounds. The north Caspian, which is an important year round habitat used for moulting, transit, foraging, resting and breeding, is an area of intensive oil and gas development and has high levels of sturgeon poaching activity which generates substantial bycatch of seals (Dmitrieva et al. 2013). In view of these environmental pressures, telemetry data can help assess impacts from human activities and contribute to conservation measures such as defining protected areas which encompass critical habitats for Caspian seals.

Acknowledgements. Primary financial and logistical support for satellite telemetry studies were provided by the North Caspian Sea Production Sharing Agreement (NCSPSA) Venture. We thank all our past and current colleagues at Agip and North Caspian Production Operation Company, particularly Olivier Pauwels, Aidyn Sakharbayev, Igor Lukashov, Sagiden Yerbulekov, Gulsim Mutysheva, Vladimir Terentiev, Davide Speranza, Samat Sarsengaliyev, Sergey Ukhov, and Giovanni Rivas for their highly professional support in logistics. We also thank all our Kazakh colleagues from the Institute of Hydrobiology and Ecology (Timur Baimukanov, Bekzat Ismagambetov), Institute of Microbiology and Virology (Aidyn Kydyrmanov, Kobey Karamendin, Yermuhammed Kasymbekov) and Kazakh Research Institute of Fisheries (Salauat Kaldybaev) with whom the fieldwork was conducted. All animal handling and use of instrumentation was in accordance with the law of Kazakhstan where the work was performed, and was carried out under permits issued by the Ural-Caspian Interregional Inspectorate of the Fisheries Committee of the Ministry of Agriculture of the Republic of Kazakhstan. The work was also reviewed and approved by the Research Ethics committee of the Faculty of Biological Sciences, University of Leeds.

\section{LITERATURE CITED}

Adachi T, Maresh JL, Robinson PW, Peterson SH and others (2014) The foraging benefits of being fat in a highly migratory marine mammal. Proc R Soc B 281:20142120

Andersen JM, Wiersma YF, Stenson GB, Hammill MO, Rosing-Asvid A, Skern-Maurizen M (2013) Habitat selection by hooded seals (Cystophora cristata) in the Northwest Atlantic Ocean. ICES J Mar Sci 70:173-185

Badamshin B (1966) Caspian seal and its commercial usage. Kaspijskij tjulen' i ego promyslovoe ispol'zovanie. In: Materialy konferencii 'Biologicheskie osnovy rybnogo hozjajstva na vodoemah Srednej Azii i Kazahstana', 12-17.04.1965. Nauka, Alma-Ata, p 59-62 (in Russian)

Badamshin B (1969) Life cycle of the Caspian seal. Godovoj cikl zhizni kaspijskogo tjulenja. In: Chetvertoe vsesojuz- 
noe soveshhanie po izucheniju morskih mlekopitajushhih. Moscow, p 218-222 (in Russian)

Bandpei MA, El-Sayed AFM, Pourgholam R, Nasrolahzadeh H, Valinassab T (2012) Food and feeding habits of the Caspian marine shad, Alosa braschnikowi (Clupeidae) in the southern Caspian Sea. Cybium 36:411-416

Benoit-Bird KJ, Battaile BC, Heppell SA, Hoover B and others (2013) Prey patch patterns predict habitat use by top marine predators with diverse foraging strategies. PLOS ONE 8:e53348

Bestley S, Jonsen ID, Hindell MA, Guinet C, Charrassin JB (2013) Integrative modelling of animal movement: incorporating in situ habitat and behavioural information for a migratory marine predator. Proc R Soc B 280:20122262

Beyer HL (2012) Geospatial modelling environment (Version 0.7.1.0). www.spatialecology.com/gme

Breed GA, Jonsen ID, Myers RA, Bowen WD, Leonard ML (2009) Sex-specific, seasonal foraging tactics of adult grey seals (Halichoerus grypus) revealed by state-space analysis. Ecology 90:3209-3221

Breed GA, Bowen WD, Leonard ML (2013) Behavioral signature of intraspecific competition and density dependence in colony-breeding marine predators. Ecol Evol 3: 3838-3854

Chambert T, Rotella JJ, Garrott RA (2015) Female Weddell seals show flexible strategies of colony attendance related to varying environmental conditions. Ecology 96: $479-488$

Charnov EL (1976) Optimal foraging, marginal value theorem. Theor Popul Biol 9:129-136

Coltman DW, Stenson G, Hammill MO, Haug T, Davis S, Fulton TL (2007) Panmictic population structure in the hooded seal (Cystophora cristata). Mol Ecol 16: 1639-1648

Crawford JA, Frost KJ, Quakenbush LT, Whiting A (2012) Different habitat use strategies by subadult and adult ringed seals (Phoca hispida) in the Bering and Chukchi seas. Polar Biol 35:241-255

De Vos A, O'Riain MJ (2013) Movement in a selfish seal herd: Do seals follow simple or complex movement rules? Behav Ecol 24:190-197

> Dietz R, Teilmann J, Andersen SM, Riget F, Olsen MT (2013) Movements and site fidelity of harbour seals (Phoca vitulina) in Kattegat, Denmark, with implications for the epidemiology of the phocine distemper virus. ICES J Mar Sci 70:186-195

Dmitrieva L (2013) The abundance, habitat use and conservation of Caspian seals (Pusa caspica). PhD thesis, University of Leeds

> Dmitrieva L, Kondakov AA, Oleynikov E, Kydyrmanov A and others (2013) Assessment of Caspian seal by-catch in an illegal fishery using an interview-based approach. PLOS ONE 8:e67074

Dmitrieva L, Härkönen T, Baimukanov M, Bignert A and others (2015) Inter-year variation in pup production of Caspian seals Pusa caspica 2005-2012 determined from aerial surveys. Endang Species Res 28:209-223

> Fedak MA, Anderson SS, Curry MG (1983) Attachment of a radio tag to the fur of seals. J Zool 200:298-300

Folkow LP, Nordey ES, Blix AS (2004) Distribution and diving behaviour of harp seals (Pagophilus groenlandicus) from the Greenland Sea stock. Polar Biol 27:281-298

Freitas C, Kovacs KM, Ims RA, Fedak MA, Lydersen C (2008a) Ringed seal post-moulting movement tactics and habitat selection. Oecologia 155:193-204
Freitas C, Kovacs KM, Ims RA, Lydersen C (2008b) Predicting habitat use by ringed seals (Phoca hispida) in a warming Arctic. Ecol Modell 217:19-32

Fr eitas C, Lydersen C, Fedak MA, Kovacs KM (2008c) A simple new algorithm to filter marine mammal Argos locations. Mar Mamm Sci 24:315-325

Fulton TL, Strobeck C (2010) Multiple markers and multiple individuals refine true seal phylogeny and bring molecules and morphology back in line. Proc R Soc B 277: 1065-1070

Gales NJ, Bowen WD, Johnston DW, Kovacs KM and others (2009) Guidelines for the treatment of marine mammals in field research. Mar Mamm Sci 25:725-736

Gjertz I, Kovacs KM, Lydersen C, Wiig O (2000) Movements and diving of adult ringed seals (Phoca hispida) in Svalbard. Polar Biol 23:651-656

Härkönen T (IUCN SSC Pinniped Specialist Group) (2008) Pusa caspica. The IUCN Red List of Threatened Species, Version 20141. http://dx.doi.org/10.2305/IUCN.UK.2008. RLTS.T41669A10532115.en

Härkönen T, Jüssi M, Baimukanov M, Bignert A and others (2008a) Pup production and breeding distribution of the Caspian seal (Phoca caspica) in relation to human impacts. Ambio 37:356-361

Härkönen T, Jüssi M, Jüssi I, Verevkin M and others (2008b) Seasonal activity budget of adult Baltic ringed seals. PLoS ONE 3:e2006

Härkönen $\mathrm{T}$, Harding $\mathrm{KC}$, Wilson $\mathrm{S}$, Baimukanov $\mathrm{M}$, Dmitrieva L, Svensson CJ, Goodman SJ (2012) Collapse of a marine mammal species driven by human impacts. PLOS ONE 7:e43130

Harvey V, Hammill MO, Swain DP, Breed GA, Lydersen C, Kovacs KM (2012) Winter foraging by a top predator, the grey seal Halichoerus grypus, in relation to the distribution of prey. Mar Ecol Prog Ser 462:273-286

Hoskins AJ, Costa DP, Arnould JPY (2015) Utilisation of intensive foraging zones by female Australian fur seals. PLOS ONE 10:e0117997

Jonsen ID, Flenming JM, Myers RA (2005) Robust statespace modeling of animal movement data. Ecology 86: 2874-2880

Jonsen ID, Myers RA, James MC (2006) Robust hierarchical state-space models reveal diel variation in travel rates of migrating leatherback turtles. J Anim Ecol 75:1046-1057

Kelly BP, Badajos OH, Kunnasranta M, Moran JR, MartinezBakker M, Wartzok D, Boveng P (2010) Seasonal home ranges and fidelity to breeding sites among ringed seals. Polar Biol 33:1095-1109

Kernaléguen L, Arnould JPY, Guinet C, Cherel Y (2015) Determinants of individual foraging specialization in large marine vertebrates, the Antarctic and subantarctic fur seals. J Anim Ecol 84:1081-1091

> Kotliar NB, Wiens JA (1990) Multiple scales of patchiness and patch structure - a hierarchical framework for the study of heterogeneity. Oikos 59:253-260

Krylov VI, Vorozhtsov GA (1972) Study of pupping period of the Caspian seal on the ice of North Caspian. Izucheniye detskogo perioda zhizni kaspiyskogo tyulenya vo l'dakh Severnogo Kaspiya. In: Tezisy dokladov 5 vsesojuznogo soveshhanija po izucheniju morskih mlekopitajushhikh, 19-21 Sep 1972. Makhachkala, p 43-48 (in Russian)

> Lake S, Burton H, Wotherspoon S (2006) Movements of adult female Weddell seals during the winter months. Polar Biol 29:270-279

> Lunn DJ, Thomas A, Best N, Spiegelhalter D (2000) Win- 
BUGS - a Bayesian modelling framework: concepts, structure, and extensibility. Stat Comput 10:325-337

Martinez-Bakker ME, Sell SK, Swanson BJ, Kelly BP, Tallmon DA (2013) Combined genetic and telemetry data reveal high rates of gene flow, migration, and longdistance dispersal potential in Arctic ringed seals (Pusa hispida). PLOS ONE 8:e77125.

Mazzaro LM, Dunn JL (2009) Descriptive account of longterm health and behavior of two satellite-tagged captive harbor seals Phoca vitulina. Endang Species Res 10: 159-163

Nathan R, Getz WM, Revilla E, Holyoak M, Kadmon R, Saltz D, Smouse PE (2008) A movement ecology paradigm for unifying organismal movement research. Proc Natl Acad Sci USA 105:19052-19059

Nyakatura K, Bininda-Emonds ORP (2012) Updating the evolutionary history of Carnivora (Mammalia): a new species-level supertree complete with divergence time estimates. BMC Biol 10:12

Patterson TA, McConnell BJ, Fedak MA, Bravington MV, Hindell MA (2010) Using GPS data to evaluate the accuracy of state-space methods for correction of Argos satellite telemetry error. Ecology 91:273-285

Peterson SH, Lance MM, Jeffries SJ, Acevedo-Gutierrez A (2012) Long distance movements and disjunct spatial use of harbor seals (Phoca vitulina) in the inland waters of the Pacific Northwest. PLOS ONE 7:e39046

Pochtoeva-Zakharova N, Huraskin L (1999) O pitanii kaspijskogo tjulenja. Rybnoe hozjaystvo 2:43-44

R Core Team (2014) R: a language and environment for statistical computing. R Foundation for Statistical Computing, Vienna

Robinson PW, Costa DP, Crocker DE, Pablo Gallo-Reynoso J and others (2012) Foraging behavior and success of a mesopelagic predator in the northeast Pacific Ocean: insights from a data-rich species, the northern elephant seal. PLOS ONE 7:e36728

Stephens DW (2008) Decision ecology: foraging and the

Editorial responsibility: Scott Shaffer,

San Jose, California, USA ecology of animal decision making. Cogn Affect Behav Neurosci 8:475-484

Sterling JT, Springer AM, Iverson SJ, Johnson SP and others (2014) The sun, moon, wind, and biological imperativeshaping contrasting wintertime migration and foraging strategies of adult male and female northern fur seals (Callorhinus ursinus). PLOS ONE 9:e93068

Stewart BS, Petrov EA, Baranov EA, Timonin A, Ivanov M (1996) Seasonal movements and dive patterns of juvenile Baikal seals, Phoca sibirica. Mar Mamm Sci 12:528-542

Svensson CJ (2012) Seal dynamics on the Swedish west coast: scenarios of competition as Baltic grey seal intrude on harbour seal territory. J Sea Res 71:9-13

Svitoch AA (2012) The Caspian Sea shelf during the pleistocene regressive epochs. Oceanology (Mosc) 52:526-539

Thompson PM, Miller D (1990) Summer foraging activity and movements of radio-tagged common seals (Phoca vitulina L.) in the Moray Firth, Scotland. J Appl Ecol 27: 492-501

Thompson D, Moss SEW, Lovell P (2003) Foraging behaviour of South American fur seals Arctocephalus australis: extracting fine scale foraging behaviour from satellite tracks. Mar Ecol Prog Ser 260:285-296

Villegas-Amtmann S, Jeglinski JWE, Costa DP, Robinson PW, Trillmich F (2013) Individual foraging strategies reveal niche overlap between endangered Galapagos pinnipeds. PLOS ONE 8:e70748

> Weimerskirch H, Pinaud D, Pawlowski F, Bost CA (2007) Does prey capture induce area-restricted search? A finescale study using GPS in a marine predator, the wandering albatross. Am Nat 170:734-743

Wildlife Computers (2011) SPLASH 2011. User guide, Version 03 Feb 2011. http://wildlifecomputers.com/wp-content/ uploads/manuals/MK10-User-Guide.pdf

> Wilson SC, Eybatov TM, Amano M, Jepson PD, Goodman SJ (2014) The role of canine distemper virus and persistent organic pollutants in mortality patterns of Caspian seals (Pusa caspica). PLOS ONE 9:e99265

Submitted: August 3, 2015; Accepted: June 14, 2016 Proofs received from author(s): July 18, 2016 